\title{
Geology
}

\section{Evidence against subduction-related magmatism for the Jiaoziyan Gabbro, northern Dabie Shan, China}

Chin-Ho Tsai, Ching-Hua Lo, Juhn G. Liou and Bor-ming Jahn

Geology 2000;28;943-946

doi: 10.1130/0091-7613(2000)28<943:EASMFT>2.0.CO;2

\section{Email alerting services}

Subscribe

Permission request click www.gsapubs.org/cgi/alerts to receive free e-mail alerts when new articles cite this article

click www.gsapubs.org/subscriptions/ to subscribe to Geology

click http://www.geosociety.org/pubs/copyrt.htm\#gsa to contact GSA

Copyright not claimed on content prepared wholly by U.S. government employees within scope of their employment. Individual scientists are hereby granted permission, without fees or further requests to GSA, to use a single figure, a single table, and/or a brief paragraph of text in subsequent works and to make unlimited copies of items in GSA's journals for noncommercial use in classrooms to further education and science. This file may not be posted to any Web site, but authors may post the abstracts only of their articles on their own or their organization's Web site providing the posting includes a reference to the article's full citation. GSA provides this and other forums for the presentation of diverse opinions and positions by scientists worldwide, regardless of their race, citizenship, gender, religion, or political viewpoint. Opinions presented in this publication do not reflect official positions of the Society.

\section{Notes}




\title{
Evidence against subduction-related magmatism for the Jiaoziyan Gabbro, northern Dabie Shan, China
}

\author{
Chin-Ho Tsai* \\ Ching-Hua Lo \\ Department of Geology, National Taiwan University, Taipei 106, Taiwan \\ Juhn G. Liou \\ Department of Geological and Environmental Sciences, Stanford University, Stanford, California 94305, USA \\ Bor-ming Jahn \\ Geosciences Rennes, Centre National de la Recherche Scientific, Université de Rennes 1, 35042, Rennes cedex, France
}

\begin{abstract}
The largest gabbroic intrusion, Jiaoziyan, in the Northern Orthogneiss of the Dabie Shan was investigated to test whether such intrusions represent arc-related or collision-related magma, as postulated in recent regional tectonic models. The Jiaoziyan intrusions comprise a gabbro-monzogabbro suite and are locally characterized by cumulus textured anhydrous silicates. Petrologic indications against arc magmatism include (1) coexisting olivine-plagioclase compositions beyond the documented range of arc gabbros, and (2) a compositional trend of $\mathrm{Al} / \mathrm{Ti}$ ratios in the gabbroic clinopyroxenes that is significantly different from subductionrelated gabbros worldwide. In contrast, the Jiaoziyan rocks are mineralogically similar to rift gabbros. Geochronologic and geometric arguments against collision-related magmatism (i.e., as a consequence of slab breakoff) include the following: (1) crystallization of the Jiaoziyan mafic intrusion postdated the Triassic (245-240 Ma) subduction and peak orogenic metamorphism by $\sim 100$ m.y. and (2) the rocks of the Dabie Cretaceous magmatic suite, including Jiaoziyan, are on the footwall plate, rather than on the hanging wall, of the Triassic subduction-zone framework and do not show a linear distribution. These observations argue that the voluminous Early Cretaceous magmatism in the Northern Orthogneiss is geodynamically unrelated to the QinlingDabie orogeny, but was caused by extensional tectonism related to regional magmatic underplating beneath the thinned Dabie crust.
\end{abstract}

Keywords: gabbros, petrogenesis, extension tectonics, Cretaceous, Dabie Mountains.

\section{INTRODUCTION}

The Dabie Shan terrane, a fault-bounded block in the Qinling-Tongbai-Dabie-Sulu orogen, preserves evidence of Triassic continental subduction, ultrahigh-pressure (UHP) metamorphism, and collision between the Yangtze and SinoKorea cratons in eastern China (Hacker et al., 1996; Fig. 1). Several critical but unsolved problems regarding the regional tectonic framework of the Dabie block include the following. (1) Where is the (missing) magmatic arc that is supposed to have existed during the Triassic subduction (Liou et al., 1996)? (2) What caused the generation of voluminous post-UHP intrusions in the region (Ratschbacher et al., 2000)? (3) Is there any truly collision-related magmatism as postulated in the literature (cf. Ma et al., 1998; Jahn et al., 1999)? To better answer these questions, this study provides new petrologic and geochemical data for the largest mafic intrusion (Jiaoziyan) of the Northern Orthogneiss unit (Hacker et al., 1995) of the Dabie Shan. The results indicate that these virtually undeformed, unmetamorphosed mafic rocks

*E-mail: tsai@gl.ntu.edu.tw. may have been generated by an extension-related tectonism unrelated to the Triassic regional subduction and collision sequence. Common denotations for the Dabie intrusions used in previous studies, such as postcollisional magmatism, are ambiguous and should not be used without clear definition and justification (cf. Liégeois, 1998).

Field, petrochemical, geochronological, and geophysical data from the European Alps, Tibetan plateau, southeastern Asia, and western Mediterranean areas (e.g., von Blanckenburg and Davies, 1995; Seber et al., 1996; Turner et al., 1996) demonstrated that syncollision to postcollision magmatism is a natural consequence of orogeny. However, for the archetypal UHP orogen - the Dabie mountain range of eastern China (Fig. 1), no evidence of orogeny-related magmatism has been found, despite the regional distribution of undeformed granitic-monzonitic-tonalitic plutons and gabbroic-pyroxenitic intrusions.

\section{GEOLOGIC BACKGROUND}

The Qinling-Tongbai-Dabie-Sulu orogenic sequence is a product of the Triassic subduction and continental collision by which the Yangtze craton (or a microcontinent) was thrust northward beneath the Sino-Korean craton (Ernst and Liou, 1995; Hacker et al., 1996). Dates on zircons in the UHP metamorphic rocks indicate that the continental collision occurred between ca. 245 and 219 Ma (Ames et al., 1996; Rowley et al., 1997; Hacker et al., 1998). The Dabie block has attracted attention because of its UHP minerals (e.g., coesite and microdiamond) in metamorphosed crustal rocks (see review by Liou et al., 1996, and references therein). Recent scientific research has focused on the Northern Orthogneiss because the unit occupies a large part of the Dabie block and contains former supersilicic clinopyroxenes that imply Triassic UHP metamorphism, yet no unambiguous UHP evidence has been found (Tsai and Liou, 2000). One of the significant features of the Northern Orthogneiss is the wide distribution of small mafic-ultramafic bodies (Fig. 1). Two types of mafic-ultramafic masses have been recognized: deformed alpinetype metaperidotites (Zhang et al., 1996; Tsai et al., 2000) and undeformed intrusions (Jahn et al., 1999). Intrusive mafic-ultramafic rocks are the present focus.

Data Repository item 200098 contains additional material related to this article. 


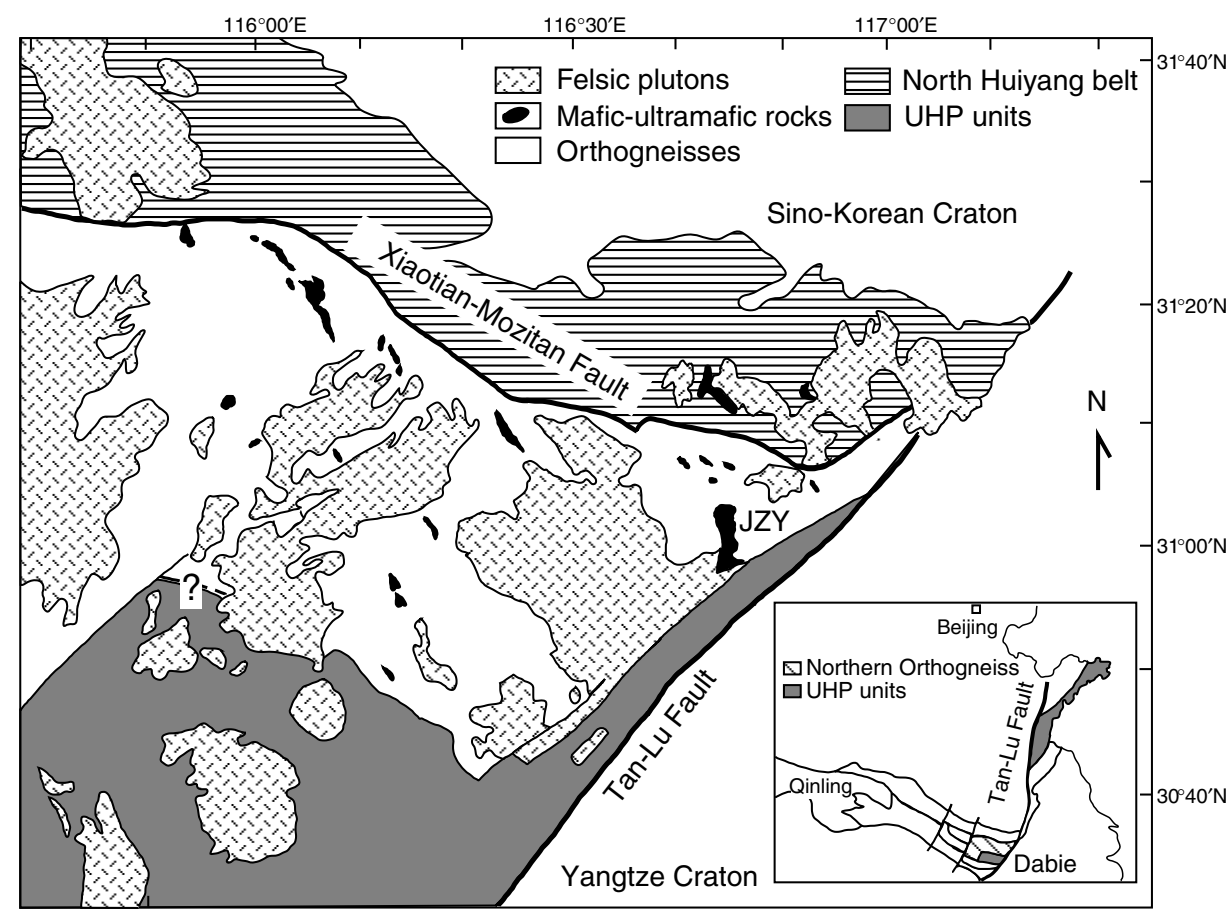

Figure 1. Simplified geologic map of Dabie Shan region (modified from Jahn et al., 1999). JZYJiaoziyan; UHP—ultrahigh presure.

The locus of the paleosuture in the Dabie region has not been conclusively defined due to lack of surface geologic evidence. On the basis of the geographic distribution of U-Pb zircon ages, Hacker et al. (1998) proposed a paleosuture zone along the northern edge of the Northern Orthogneiss. If true, the proposed suture implies that no arc-related rocks should be found in the Northern Orthogneiss (i.e., the footwall plate). In contrast, Zhai et al. (1994) suggested an Andeantype magmatic arc setting for the Northern Orthogneiss. Isotopic age data show that most granitic plutons and mafic-ultramafic intrusions in the Northern Orthogneiss were emplaced during the Early Cretaceous, postdating the Triassic subduction and collision. Investigation is needed to determine whether the magmatism can be attributed to an orogeny-related, postcollisional mechanism (e.g., slab breakoff; cf. Ma et al., 1998; Jahn et al., 1999), Cretaceous subduction of the Pacific plate (Ratschbacher et al., 2000), or another mechanism.

The Northern Orthogneiss is dominated by variably deformed orthogneisses and virtually undeformed granitic-monzonitic-tonalitic plutons. Regional structural data indicate that the unit is an asymmetric magmatic-structural dome formed during Cretaceous northwest-southeast subhorizontal extension (Hacker et al., 1995). Ratschbacher et al. (2000) have suggested that the Northern Orthogneiss may be regarded as a metamorphic core complex that is part of a chain of Pacific backarc extensional systems. The Jiaoziyan Gabbro ( $36 \mathrm{~km}^{2}$ in outcrop area) is the largest mafic intrusion exposed in the North- ern Orthogneiss and is $\sim 6 \mathrm{~km}$ west of the Tan-Lu fault and $\sim 15 \mathrm{~km}$ south of the Xiaotian-Mozitan fault (Fig. 1). The Jiaoziyan gabbroic rocks show discordant intrusive contacts with country rocks, which are mainly biotite-hornblende-bearing (tonalitic) orthogneisses associated with deformed layers of titanite-bearing amphibolite, minor allanite-hornblende-bearing quartzofeldspathic gneiss, and rare phlogopite-bearing marble (our field observations). Most orthogneisses in the unit are postulated to have undergone Cretaceous (137-134 Ma) amphibolite facies metamorphism (Hacker et al., 1998).

\section{PETROGRAPHIC CHARACTERIZATION OF THE MAFIC INTRUSIONS}

The Jiaoziyan gabbroic intrusion is massive and medium to coarse grained. From the center to the margin of the intrusion, the rock type changes gradually from olivine-bearing gabbronorite, to olivine-free gabbronorite, to orthopyroxene-free gabbro, to dioritic gabbro; the modal variation indicates a magmatic differentiation sequence. Petrographically, most of the rocks show cumulus textures; however, the intrusive body has no internal layering. Locally, fine-grained, biotite- and plagioclase-rich dikes and feldspar-rich veins cut across the gabbros.

Typically the rocks contain plagioclase, orthopyroxene, clinopyroxene, biotite, and minor (subsolidus) calcic amphibole. A few samples have olivine. Accessory minerals are ilmenite, apatite, zircon, and rare spinel. Olivine, orthopyroxene, and clinopyroxene crystals show a cumulus framework in intercumulus plagioclase.
The plagioclase oikocrysts locally contain oriented, micrometer-scale needles, probably of iron oxide (cf. Davies, 1981). The sharp contacts between olivine and plagioclase grains indicate that the gabbronorite has not been subjected to amphibolite or granulite facies metamorphism (cf. Ashworth, 1993; Liégeois, 1998), whereas amphibolite facies metamorphism is evident in the country-rock orthogneisses (Zhang et al., 1996). Such a petrographic feature implicitly forbids the claimed syncollisional (Triassic) magmatism for the mafic intrusions in the Northern Orthogneiss (e.g., Chen et al., 1997; Nie and Li, 1998). Pyroxenes commonly contain abundant oriented opaque needles and platelets, and in some cases, amphibole and biotite patches. Magmatic reaction rims of orthopyroxene around olivine and brown calcic amphibole around orthopyroxene or olivine are common. Biotite is mostly interstitial to pyroxenes and plagioclase.

\section{ANALYTICAL METHODS}

We systematically collected 21 whole-rock samples across the intrusion, and analyzed them for major element compositions; 7 of the samples were analyzed for trace and rare earth element (REE) concentrations. Major and trace element compositions were determined by X-ray fluorescence (XRF) at the GeoAnalytical Laboratory of Washington State University (USA) and at XRAL Laboratories (Canada). REE analysis was done by inductively coupled plasma-mass spectrometry (ICP-MS) at the same laboratories. Mineral compositions were determined on polished thin sections with an automated, 5-spectrometer JEOL 733 electron microprobe at Stanford University; operating conditions were $15 \mathrm{keV}$ accelerating voltage and $15 \mathrm{nA}$ beam current with $20 \mathrm{~s}$ counting time. Representative geochemical and mineralogical data for the gabbros are available. ${ }^{1}$

\section{WHOLE-ROCK AND MINERAL COMPOSITIONS}

The Jiaoziyan mafic intrusive rocks are gabbromonzogabbro in composition, according to the total alkali versus silica classification by Middlemost (1994). In terms of alkali $\left(\mathrm{K}_{2} \mathrm{O}+\mathrm{Na}_{2} \mathrm{O}\right)$ $\mathrm{FeO}_{\text {total }}-\mathrm{MgO}$ proportions, the gabbros are calcalkalic (Fig. 2A); the total alkali content increases with increasing $\mathrm{SiO}_{2}$. Chondrite-normalized multielement data demonstrate that the mafic intrusions are characterized by enriched light REE patterns similar to those reported by Jahn et al. (1999). Primitive mantle-normalized multielement patterns show characteristic negative $\mathrm{Nb}$ and $\mathrm{Ta}$ anomalies with respective to Th and light REEs (Fig. 2B). Negative $\mathrm{Nb}$ anomalies are characteristic of the continental crust; crustal involve-

${ }^{1}$ GSA Data Repository item 200098, Geochemical and mineralogical data, is available on request from Documents Secretary, GSA, P.O. Box 9140, Boulder, CO 80301-9140, editing@geosociety.org, or at www. geosociety.org/pubs/ft2000.htm. 
Figure 2. A: Whole-rock alkali-

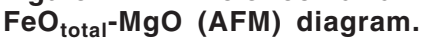
B: Multielement patterns for Jiaoziyan gabbroic rocks; primitive-mantle normalization factors are after Jahn et al. (1999).
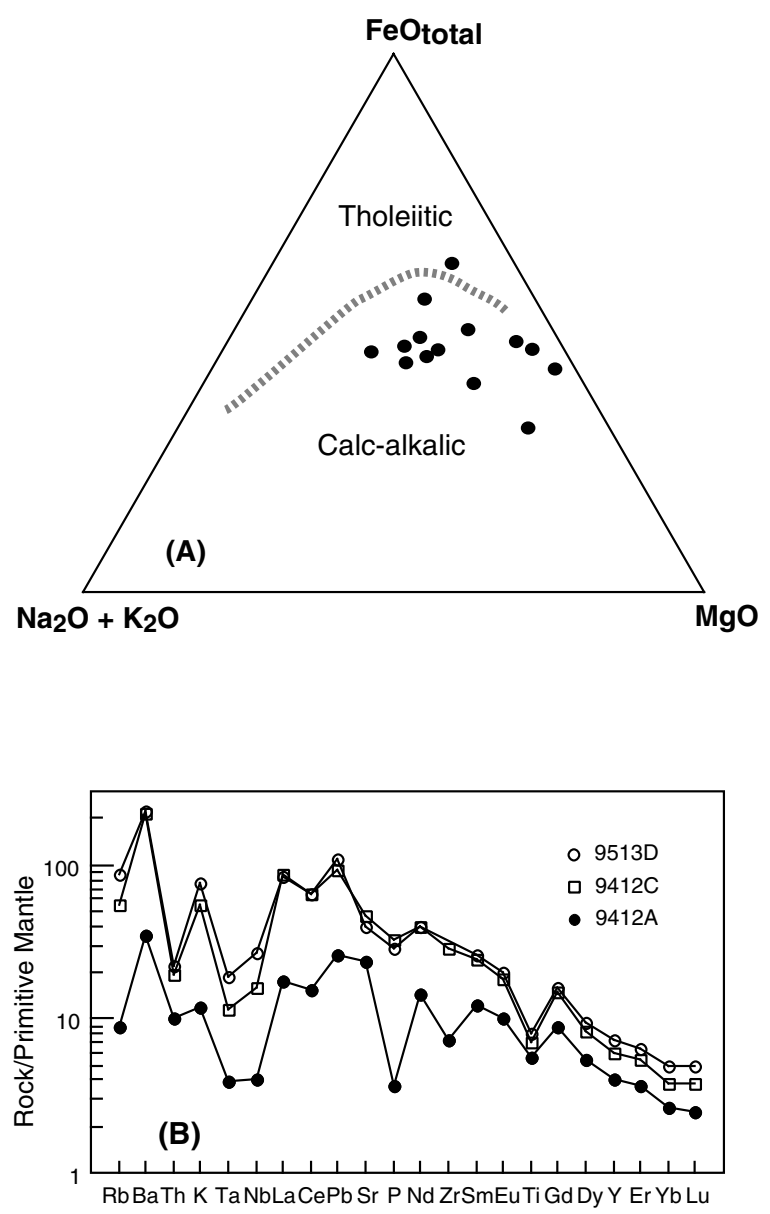

ment in the Jiaoziyan magma generation is implied, although no distinction can be made with regard as to whether the crustal signature was from subducted sediments or from older basement rocks such as granulite (Jahn et al., 1999). Olivine and orthopyroxene compositions of the Jiaoziyan Gabbro average $\mathrm{Fo}_{72-74}$ and $\mathrm{En}_{65-73}$, respectively. Clinopyroxene compositions are $\mathrm{Wo}_{40-46} \mathrm{En}_{40-46} \mathrm{Fs}_{11-15}$ and plagioclase compositions range from $\mathrm{An}_{62}$ to $\mathrm{An}_{30}$. Biotite contains significant $\mathrm{Ti}\left(\sim 4-6 \mathrm{wt} \% \mathrm{TiO}_{2}\right)$. Calcic amphibole is pargasite to magnesiohornblende.

\section{GEOCHRONOLOGICAL CONSTRAINTS}

Field relationships clearly show that the Jiaoziyan Gabbro structurally postdated the country-rock orthogneisses. Recent ${ }^{40} \mathrm{Ar} /{ }^{39} \mathrm{Ar}$, $\mathrm{Rb}-\mathrm{Sr}$, and $\mathrm{Sm}-\mathrm{Nd}$ ages indicate that cooling (to $\leq 500-300^{\circ} \mathrm{C}$ ) of mafic intrusions of the Northern Orthogneiss, including the Jiaoziyan, occurred ca. 133-120 Ma (e.g., Hacker and Wang, 1995; Tsai, 1998; Jahn et al., 1999; Ratschbacher et al., 2000). In contrast, Xue et al. (1997) and Hacker et al. (1998) showed that (1) amphibolite facies metamorphic ages of the bulk orthogneisses are in the range 137-134 Ma and (2) crystallization ages of granitic-tonalitic plutons are in the range 134-126 Ma. With respect to these data, the mafic intrusions were coeval with the much larger granitic plutons in the Northern Orthogneiss, but substantially postdated the amphibolite facies metamorphism of the orthogneisses.

\section{DISCUSSION}

The Jiaoziyan gabbros resemble calc-alkalic or tholeiitic arc rocks with negative $\mathrm{Nb}$-Ta anomalies and enriched light REE patterns (Zhai et al., 1994; cf. DeBari, 1994). However, subsolidus reequilibration and open-system modification of gabbroic rocks may cause serious problems with petrogenetic interpretations. Furthermore, the magmatic rocks in the Dabie block postdate the regional convergence and lead to the common label of postcollisional magmatism (Zhang et al., 1996; Ma et al., 1998). However, as we discuss herein, the mineral composition, intrusion-cooling age, and regional tectonic framework do not support such speculations.

\section{Implications Against Arc Magmatism}

Beard (1986) proposed that compositions of coexisting olivine and plagioclase in gabbro cumulates are a good indicator of the tectonic setting of ancient volcano-plutonic complexes. Among the Jiaoziyan gabbroic rocks, olivine occurs only in a few samples from the intrusion core and has a narrow compositional range. Plagioclase occurs as either an intercumulus
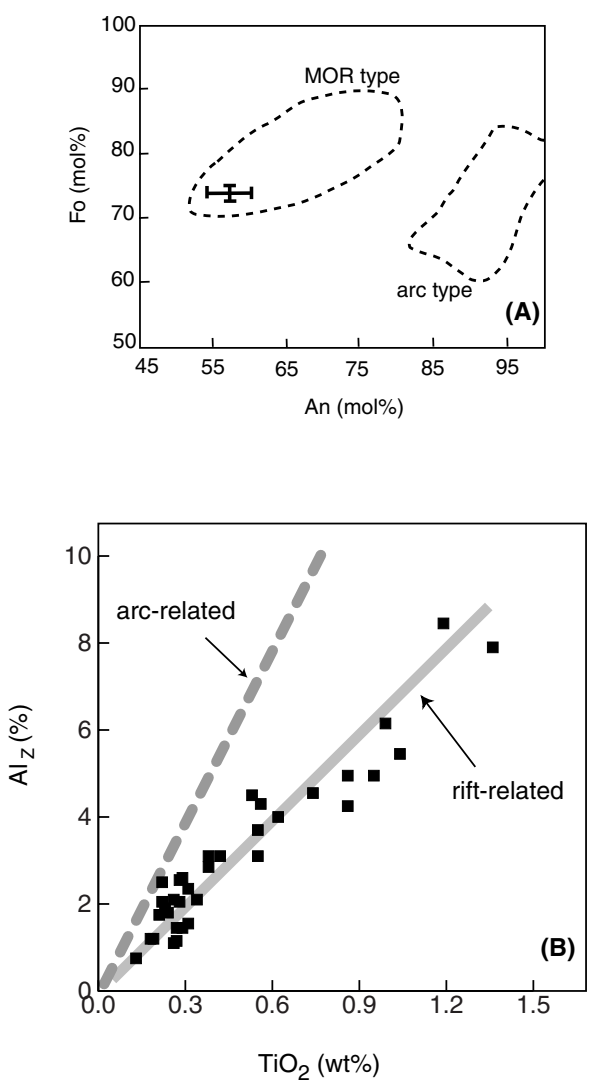

Figure 3. Compositional correlations for Jiaoziyan gabbros. A: Forsterite content in olivine vs. anorthite content in plagioclase

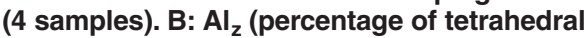
sites occupied by Al) vs. $\mathrm{TiO}_{2}$ (wt\%) in clinopyroxene (9 samples). Fields of arc-related and slow-spreading ridge cumulates (midocean ridge [MOR] type) in A are from Beard (1986) and Elthon et al. (1992), respectively; reference lines in B are from Loucks (1990).

phase (in the relatively primitive samples) or as a cumulus phase (in the relatively evolved samples). The Jiaoziyan plagioclase and olivine compositions are distinctly different from those of arc gabbros (cf. Beard, 1986; DeBari, 1994; Fig. 3A). Furthermore, Loucks (1990) demonstrated that the correlations between $\mathrm{Al}_{\mathrm{z}}$ (percentage of tetrahedral sites occupied by $\mathrm{Al}$ ) and $\mathrm{TiO}_{2}(\mathrm{wt} \%$ ) of clinopyroxenes can be used to discriminate between arc-related and rift-related gabbros. The Jiaoziyan gabbroic clinopyroxenes compositional trend is clearly different from the arcrelated one (Fig. 3B).

\section{Implications Against Collision-Related Magmatism}

In previous models, it has been implied that the bimodal (felsic and mafic) magmatism in the Northern Orthogneiss was caused by either slab breakoff or lithospheric-mantle thinning (Zhang et al., 1996; Ma et al., 1998; Jahn et al., 1999). Both magmatic end members have been attributed to postcollisional magmatism in recent literature. In terms of timing, isotopic ages show that 
the Jiaoziyan Gabbro and other mafic-ultramafic intrusions of the Northern Orthogneiss were emplaced in the Early Cretaceous, postdating the Triassic regional subduction and continental collision. However, the huge time gap ( 100 m.y.) between the magmatism and peak orogenic metamorphism and deformation is beyond the range in which magmatism can be unambiguously considered as orogeny related (Turner et al., 1992; Liégeois, 1998) In addition, there are no geometric grounds to support the slab breakoff model for generation of the voluminous Dabie plutons because the rocks intruded into the footwall plate of the Triassic subduction-zone system, not close to the suture zone or within the hanging wall (cf. Davies and von Blanckenburg, 1995; Hacker et al., 1998).

\section{SUMMARY}

1. Petrologic and geochronologic data indicate that the mafic intrusions in the Northern Orthogneiss, and probably their coeval counterparts through the entire Dabie block, are not subduction or collision related. Our new data show no support for previous speculations about (1) an Andean-type magmatic arc (Zhai et al., 1994), (2) slab breakoff-driven magmatism (Ma et al., 1998), or (3) syncollisional intrusion (Chen et al., 1997; Nie and Li, 1998) in the Northern Orthogneiss. It seems more probable that extensional tectonism was the major mechanism for the emplacement of the Cretaceous magmatic suites (cf. Ratschbacher et al., 2000).

2. Due to the lack of extrusive rocks in the Dabie block south of the Xiaotian-Mozitan fault, it is difficult to place a good constraint on the magma source and its driving mechanism for the Cretaceous magmatism. It remains unclear whether the widely distributed mafic and felsic plutons in the Dabie Shan belong to Mesozoic intercraton-scale extension-related magma system(s) along eastern China (Li, 2000; Ratschbacher et al., 2000) or represent a relatively localized Cretaceous hotspot that magmatically underplated the thinned Dabie crust (Jahn et al., 1999).

\section{ACKNOWLEDGMENTS}

Discussion with J.H. Davies and comments by R.J. Beane and W.G. Ernst have improved an early draft of this paper. Reviews by B.R. Hacker and an anonymous reader are greatly appreciated. We thank B. Cong, D. Chen, and Y. Wu for logistical assistance. This research was supported by grant EAR-9506468 (to Liou) from the U.S. National Science Foundation and by grant NSC89-2116-M002-018 (to Lo) from the R.O.C. National Science Council.

\section{REFERENCES CITED}

Ames, L., Zhou, G., and Xiong, B., 1996, Geochronology and isotopic character of ultrahigh-pressure metamorphism with implications for collision of the Sino-Korean and Yangtze cratons, central China: Tectonics, v. 15, p. 172-489.

Ashworth, J.R., 1993, Fluid-absent diffusion kinetics of Al inferred from retrograde metamorphic coronas: American Mineralogist, v. 78, p. 331-337.
Beard, J.S., 1986, Characteristic mineralogy of arcrelated cumulate gabbros: Implications for the tectonic setting of gabbroic plutons and for andesite genesis: Geology, v. 14, p. 848-851.

Chen, D., Wu, Y., Xia, Q., Zh, X., Wang, Y., and Yang, J., 1997, The Sm-Nd age and Nd isotopic characterization of Jiaoziyan gabbroic intrusion: Acta Geoscientia Sinica, v. 18, supplement, p. 9-11 (in Chinese).

Davies, J.H., and von Blanckenburg, F., 1995, Slab breakoff: A model of lithosphere detachment and its test in the magmatism and deformation of collisional orogens: Earth and Planetary Science Letters, v. 129, p. 85-102.

Davies, K.E., 1981, Magnetite rods in plagioclase as the primary carrier of stable NRM in ocean floor gabbros: Earth and Planetary Science Letters, v. 55 , p. $190-198$.

DeBari, S.M., 1994, Petrogenesis of the Fiambalá Gabbroic Intrusion, northwestern Argentina, a deep crustal syntectonic pluton in a continental magmatic arc: Journal of Petrology, v. 35, p. 679-713.

Elthon, D., Stewart, M., and Ross, K.M., 1992, Compositional trends of minerals in oceanic cumulates: Journal of Geophysical Research, v. 97, p. $15,189-15,199$.

Ernst, W.G., and Liou, J.G., 1995, Contrasting platetectonic styles of the Qinling-Dabie-Sulu and Franciscan metamorphic belts: Geology, v. 23, p. 353-356.

Hacker, B.R., and Wang, Q., 1995, Ar/Ar geochronology of ultrahigh-pressure metamorphism in central China: Tectonics, v. 14, p. 994-1006.

Hacker, B.R., Ratschbacher, L., Webb, L., and Dong, S., 1995, What brought them up? Exhumation of the Dabie Shan ultrahigh-pressure rocks: Geology, v. 23, p. 743-746.

Hacker, B.R., Wang, X., Eide, E.A., and Ratschbacher, L., 1996, Qinling-Dabie ultrahigh-pressure collisional orogeny, in Yin, A., and Harrison, T.M., eds., The tectonic evolution of Asia: Cambridge, UK, Cambridge University Press, p. 345-370.

Hacker, B.R., Ratschbacher, L., Webb, L., Ireland, T., Walker, D., and Dong, S., 1998, U/Pb zircon ages constrain the architecture of the ultrahigh-pressure Qinling-Dabie orogen, China: Earth and Planetary Science Letters, v. 161, p. 215-230.

Jahn, B.M., Wu, F., Lo, C.H., and Tsai, C.H., 1999, Crust-mantle interaction induced by deep subduction of the continental crust: Geochemical and $\mathrm{Sm}-\mathrm{Nd}$ isotopic evidence from post-collisional mafic-ultramafic intrusions of the northern Dabie complex, central China: Chemical Geology, v. 157 , p. $119-146$.

Li, X.H., 2000, Cretaceous magmatism and lithospheric extension in southeast China: Journal of Asian Earth Sciences, v. 18, p. 293-305.

Liégeois, J.-P., 1998, Preface-Some words on the postcollisional magmatism: Lithos, v. 45, p. Xv-xvii.

Liou, J.G., Zhang, R.Y., Wang, X., Eide, E.A., Ernst, W.G., and Maruyama, S., 1996, Metamorphism and tectonics of high-pressure belts in the DabieSulu region, China, in Yin, A., and Harrison, T.M., eds., The tectonic evolution of Asia: Cambridge, UK, Cambridge University Press, p. 300-343.

Loucks, R.R., 1990, Discrimination of ophiolitic from nonophiolitic ultramafic-mafic allochthons in orogenic belts by the $\mathrm{Al} / \mathrm{Ti}$ ratio in clinopyroxene: Geology, v. 18, p. 346-349.

Ma, C., Li, Z., Ehlers, C., Yang, K., and Wang, R., 1998, A post-collisional magmatic plumbing system: Mesozoic granitoid plutons from the Dabieshan high-pressure and ultrahigh-pressure metamorphic zone, east-central China: Lithos, v. 45, p. 431-456.
Middlemost, E.A.K., 1994, Naming materials in the magma/igneous rock system: Earth-Science Reviews, v. 37, p. 215-224.

Nie, Y., and Li, S., 1998, Sm-Nd age of syncollisional mafic-ultramafic intrusions in the Dabie Mountains: Chinese Science Bulletin, v. 43, p. 160-163.

Ratschbacher, L., Hacker, B.R., Webb, L.E., McWilliams, M.O., Ireland, T., Dong, S., Calvert, A., Chateigner, D., and Wenk, H.-R., 2000, Exhumation of ultrahigh-pressure continental crust in east-central China: Cretaceous and Cenozoic unroofing and the Tan-Lu fault: Journal of Geophysical Research (in press).

Rowley, D.B., Xue, F., Tucker, R.D., Peng, Z.X., Baker, J., and Davis, A., 1997, Ages of ultrahigh pressure metamorphism and protolith orthogneisses from the eastern Dabie Shan: $\mathrm{U} / \mathrm{Pb}$ zircon geochronology: Earth and Planetary Science Letters, v. 151, p. 191-203.

Seber, D., Barazangi, M., Ibenbrahim, A., and Demnati, A., 1996, Geophysical evidence for lithospheric delamination beneath the Alboran Sea and RiftBetic mountains: Nature, v. 379, p. 785-772.

Tsai, C.H., 1998, Petrology and geochemistry of maficultramafic rocks in the North Dabie Complex, central-eastern China [Ph.D. thesis]: Stanford, California, Stanford University, $171 \mathrm{p}$.

Tsai, C.H., and Liou, J.G., 2000, Eclogite facies relics and inferred ultrahigh-pressure metamorphism in the North Dabie Complex, central-eastern China: American Mineralogist, v. 85, p. 1-8.

Tsai, C.H., Liou, J.G., and Ernst, W.G., 2000, Petrological characterization and tectonic significance of retrogressed garnet peridotites, Raobazhai area, North Dabie Complex, east-central China: Journal of Metamorphic Geology, v. 18, p. 181-192.

Turner, S., Sandiford, M., and Foden, J., 1992, Some geodynamic and compositional constraints on "postorogenic" magmatism: Geology, v. 20, p. 931-934.

Turner, S., Arnaud, N., Liu, J., Rogers, N., Hawkesworth, C., Harris, N., Kelley, S., Van Calsteren, P. and Deng, W., 1996, Post-collision, shoshonitic volcanism on the Tibetan plateau: Implications for convective thinning of the lithosphere and the source of ocean island basalts: Journal of Petrology, v. 37, p. 45-71.

von Blanckenburg, F., and Davies, J.H., 1995, Slab breakoff: A model for syncollisional magmatism and tectonics in the Alps: Tectonics, v. 14, p. 120-131.

Xue, F., Rowley, D.B., Tucker, R.D., and Peng, Z.X., 1997, U-Pb zircon ages of granitoid rocks in the North Dabie Complex, eastern Dabie Shan, China: Journal of Geology, v. 105, p. 744-753.

Zhai, M., Cong, B., Zhang, Q., and Wang, Q., 1994, The northern Dabieshan terrane: A possible Andean-type arc: International Geology Review, v. 36, p. 867-883.

Zhang, R.Y., Liou, J.G., and Tsai, C.H., 1996, Petrogenesis of a high-temperature metamorphic terrane: A new tectonic interpretation for the north Dabie Shan, central China: Journal of Metamorphic Geology, v. 14, p. 319-333.

Manuscript received March 24, 2000

Revised manuscript received June 20, 2000

Manuscript accepted July 19, 2000 